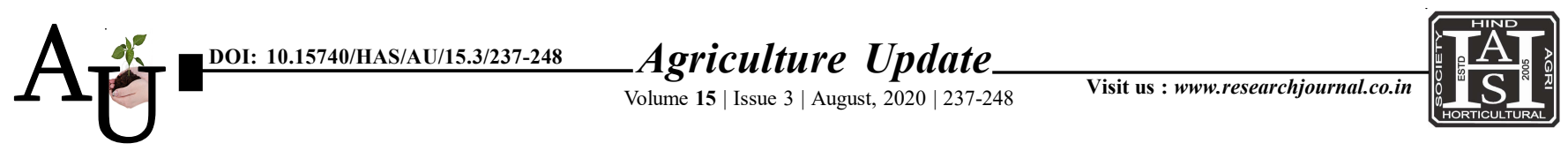

ISSN-0973-1520

\title{
Research article: Economic analysis of onion seed production in Washim district of Vidarbha region
}

Article Chronicle:

Received :

21.05.2020;

Revised:

19.06.2020;

Accepted :

21.07.2020

\section{KeY Words :}

Economic analysis, Onion seed production
Author for correspondence :

R.D. Vaidkar

Department of Agricultural Economics and Statistics, Dr. Panjabrao Deshmukh

Krishi Vidyapeeth, Akola (M.S.) India

Email: rajeshvaidkar@ yahoo.com

See end of the article for authors' affiliations
SUMMARY : The present study is undertaken to study the economics analysis of onion seed production in washim district of Vidarbha.The study was based on primary data. Primary data of 90 farmers pertaining to the year 2018-2019 were collected from three villages and functionaries involved in onion seed procurement chain producer, seed company, retailer were selected for collecting information. The onion seed production is taken on small scale but it contributes sizable share in total earning of the cultivator. However, yield and profit from onion seed cultivation is uncertain because it is very sensitive, it require special attention. To study the economics of onion seed production, the standard cost concepts were used. In estimation of cost of cultivation, seed, rental value of land, human labour and interest on fixed capital were the major cost items. The gross cropped area was highest in large group i.e. 8.28 hectare followed by medium 5.27 ha and small group 2.93. The cropping pattern of onion seed was dominated by soybean, cotton and tur in Kharif season whereas gram and wheat was Rabi season. In Rabi season the contribution of area under onion seed was $12.62,12.52$ and 12.31 per cent by small, medium and large farmers. Per hectare total cost of cultivation of onion seed was highest in the medium group i.e. Rs. 167967.3 per hectare followed by large group Rs. 166102.74 and small group Rs.165161.53.The benefit cost ratio of onion seed at cost ' $\mathrm{C}_{3}$ ' was 1.70 in small group, 1.76 in medium group and 1.78 in large group.

How to cite this article : Muley, P.D., Khobarkar, V.K. and Vaidkar, R.D. (2020). Economic analysis of onion seed production in Washim district of Vidarbha region. Agric. Update, 15(3): 237-248; DOI : 10.15740/HAS/AU/ 15.3/237-248. Copyright@ 2020: Hind Agri-Horticultural Society. 